\title{
Effects of paraffin external coating on the degradable flower pot made of sludge cake
}

\author{
Udomsak Kongmuang ${ }^{1}$, Chaovayut Phornpimolthape ${ }^{1}$ and Ikuharu Morioka ${ }^{2^{*}}$ (B)
}

\begin{abstract}
Objectives: The researchers have tried to economically make a flower pot from sludge cake produced in paper mill industries for the purpose of decreasing its volume. The crude flower pot did not resist natural sprinkling of water or natural rain. The aims of this study were to clarify two hypotheses: (1) whether life time of a degradable flower pot on the ground would be prolonged or not by coating it with appropriate material, and (2) whether paraffin, material used for coating flower pot, would prevent the toxicity of sludge cake in it.
\end{abstract}

Methods: Sludge cake was mixed with soil. The circular plaster mold was used as a fixed mold. Three types of coating materials, paraffin wax, tapioca starch and modified tapioca starch were selected. Water durability test was performed with a water sprinkler. As the toxicological testing, leaching test and seed germination test were used using the paraffin-coated flower pot.

Results: In the water durability test, the durability was different among types of the coated flower pot. Among them, the paraffin prolonged the life time of flower pot on the ground until 5 weeks at least and may be 8 weeks. The results of leaching test using the paraffin-coated flower pot showed that three heavy metals, lead, nickel and copper, were lower than the standard in Thailand, but the paraffin had no preventive effect on the leaching of the heavy metals from the sludge cake in the flower pot. The seed germination test showed no significant difference in the number of germination of Chinese kale and the length of its leaf from those grown in the plant soil, and suggested that the paraffin-coated flower pot seemed to have no suppressive effect on the seed germination of Chinese kale.

Conclusion: The paraffin prolongs the life time of flower pot on the ground. Although it has no preventive effect on the toxicity of the sludge cake in the flower pot, the paraffin-coated flower pot seems to have no negative effect on the environment. This paraffin-coated flower pot has the possibility to reuse the sludge cake in the horticultural practice of growing the ornamental plant.

\section{Introduction}

Paper mill industries in Thailand generally produce sludge cake after wastewater treatment. This sludge cake is usually disposed into an industrial open landfill $[1,2]$. Since it contains some heavy metals, especially lead [3, $4]$, it becomes one of the sources of pollutants to cause environmental degradation $[2,5]$ and health problems.

\footnotetext{
*Correspondence: moriokai@wakayama-med.ac.jp

${ }^{2}$ Graduate School of Health and Nursing Science, Wakayama Medical

University, Mikazura 580, Wakayama 641-0011, Japan

Full list of author information is available at the end of the article
}

To decrease its volume disposed into a landfill, many researchers have tried to recycle rigid materials from it and investigated its safety $[6,7]$.

The sludge is not a waste, but has a lot of fertilizing values. The application of sludge for agricultural purposes is beneficial because organic matter improves nutrients for the plant germination and growth. Thus, the sludge is used as soil amendment [8]. The sludge compost is economically reliable to grow the plant [9]. However, the sludge contains potentially toxic elements. High levels of toxic elements become the risk of health of plants and humans. When farmers plan to use the sludge, they must 
confirm whether the sludge is suitable for planting or not [10].

In the previous report [11], the researchers have tried to make a flower pot for reducing the volume of sludge cake economically. They also have clarified that the new flower pot can be made from the sludge cake with clay, and that it has the possibility to have no negative effect on the environment of disposing it. However, the flower pot does not resist natural sprinkling of water or natural rain. Thus, the researchers have discussed on the necessity of coating its surface to use it for a longer time. The material used for coating it would also have possibility to prevent the environmental degeneration and health problems of the sludge cake.

The aims of this study were to clarify two hypotheses: (1) whether life time of a degradable flower pot on the ground would be prolonged or not by coating it with appropriate material, (2) whether material used for coating it would have preventive effect on the toxicity of sludge cake in it or not.

\section{Methods}

\section{Cooperative industry}

The cooperative industry is a medium-sized (227 workers) paper mill industry in Thailand, producing approximately $4500 \mathrm{~m}^{3}$ day $^{-1}$ wastewater in 2017 . After being treated chemically using aluminum sulfate and biologically using urea, ferric chloride and phosphoric acid, and then mixed with polyacrylamide [11], the wastewater becomes sludge cake (Eurochem, Activated System). The sludge cake (about $5 \mathrm{~m}^{3}$ day $^{-1}$ ) is disposed into the industrial landfill.

\section{Making a flower pot}

The components of making a flower pot were a binder and a fixed model [11]. The clay in the soil was used as the binder. The soil was brought from Bang Len, Nakhon Pathom Province, Thailand (Bang Len soil). This contained sand $20.68 \%$, silt $28.30 \%$ and clay $51.02 \%$ and was classified as heavy clay (clay $>50 \%$ ). Sludge cake without cleaning $(5 \mathrm{~kg})$ was mixed with the Bang Len soil $(10 \mathrm{~kg})$ at the set ratio of sludge cake: soil by weight was $1: 2$ by a paddle [11]. Some water $(600 \mathrm{~mL})$ was added. The mixture was mixed again by the paddle until it became mushy.

Two machines were used to make the flower pot [11]. They were mixing machine, in which there were two screw parts to mix homogeneously, and shape forming (jigger) machine. The material mixed by the paddle was poured into the mixing machine. The thoroughly mixed material by the mixing machine (clay slurry) was put into the circular plaster mold as a fixed mold. This plaster mold looked like hollow cone $(12.0 \mathrm{~cm}$ height, inner diameter $15.6 \mathrm{~cm}$ at top and $9.6 \mathrm{~cm}$ at bottom). The clay slurry was poured into the plaster mold until about half of its volume. The plaster mold of the clay slurry was set under the arm of jigger machine. As the clay slurry came into contact with the vertically rotating head piece, it was pressed and spread until it finally became the shape of plaster mold.

Formations of flower pot $(1.5 \mathrm{~cm}$ thickness of wall $)$ were dried in the room for 1 day before removing from the plaster mold. They were dried for one more day in a shadow area and drilled (about $15 \mathrm{~mm}$ hole in the bottom) for root outlet and water drainage. After that, they were left out of doors for 14 days. The dried weight of flower pot ranged from 507 to $559 \mathrm{~g}$.

\section{Materials for coating the flower pot}

Three types of materials, paraffin wax, tapioca starch and modified tapioca starch were selected. Three flower pots were randomly selected for each type of materials.

\section{Paraffin wax}

Paraffin wax is a white or colorless soft solid derivable from petroleum. In a pathology laboratory, this is used to impregnate tissue prior to sectioning thin samples of the tissue [12]. This is also used for candle making, for coating for waxed paper or cloth [13], and, as sealant, for jar, cans and bottles $[14,15]$. In this study, the paraffin of good quality in white candle (Candles Lucky, Sahasriutsahagum Company) was used.

\section{Tapioca starch}

Starch accumulates in plants as a complex carbohydrate form. There are various types of starch: the common corn/maize starch, tapioca starch, and wheat, rice and potato starch. The starch is insoluble in cold water, but dissolves in warm water. Dissolved starch in warm water makes starch paste [16]. The starch paste is used as thickening, stiffening or gluing agent. In this study, the tapioca starch (Pine Brand, Sitthinan Company Ltd.) from Central Department Store, Rattanathibet, Nonthaburi Province, Thailand was used.

\section{Modified tapioca starch}

Starches are modified to enhance their performance in different applications. Modified starch has properties processed using physical, enzymatical, or chemical treatment [17]. This starch is soluble in the cold water and thickens gels without heat. This is practically used as a thickening agent, stabilizer or emulsifier in food products, as disintegrates in pharmaceuticals, and as a binder in coated paper $[18,19]$. In this paper, acid-treated modified tapioca starch (KLIC 10, SMS Corporation Company Ltd.) was used. It has the medium viscosity and dissolves in tap water at about $25^{\circ} \mathrm{C}$. 


\section{Coating the surface of flower pot Paraffin wax}

Solid paraffin wax in sheet form (about $7.5 \mathrm{~kg}$ ) was put into the stainless pot. It was heated by a temperature controller of stove until all paraffin completely became liquid. The temperature of the liquid paraffin was kept at $90-95{ }^{\circ} \mathrm{C}$ until the coating process was finished. The temperature was checked by a thermometer every $5 \mathrm{~min}$. The flower pot suspended by a rope was immersed into the liquid paraffin for $10 \mathrm{~s}$. The immersed flower pot was left at the room temperature for at least 1 day. The weight of the paraffin used for coating ranged from 15.0 to 17.8 grams (3 samples: average $16.7 \mathrm{~g}, 3.1 \mathrm{~g}$ per pot by $100 \mathrm{~g}$ ).

\section{Tapioca starch}

Four hundred milliliter hot water at $80{ }^{\circ} \mathrm{C}$ was poured on $150 \mathrm{~g}$ tapioca starch in a pail with stirring it uniformly and rather quickly. This solution of tapioca starch was heated by a heater up to $205{ }^{\circ} \mathrm{C}$. When stirring the solution became tough and rather difficult, $150 \mathrm{~mL}$ water was poured. Stirring it was continued until the solution became milky color, namely the solution became starch paste. When the starch paste had high viscosity by the finger testing, the solution was cooled until about $90{ }^{\circ} \mathrm{C}$. Using a clean brush, the starch paste painted all surface of the flower plot. The painted flower pot was dried at the room temperature for at least 1 day. The weight of the starch paste used for coating ranged from 28.1 to 29.8 grams (3 samples: average $29.0 \mathrm{~g}, 5.4 \mathrm{~g}$ per pot by $100 \mathrm{~g}$ ).

\section{Modified tapioca starch}

One hundred milliliter water at $29^{\circ} \mathrm{C}$ was poured on 50 g modified tapioca starch in a pail with stirring it uniformly and rather quickly. When stirring the solution became tough and rather difficult, $150 \mathrm{~mL}$ water was poured. In total, $250 \mathrm{~mL}$ water was warmed by a heater and stirring was continued at $60{ }^{\circ} \mathrm{C}$ for $10 \mathrm{~min}$. When the solution became brown jelly and had high viscosity by the finger testing, namely the solution became modified starch paste, stirring was stopped. Using a clean brush, the modified starch paste painted all surface of the flower plot. The painted flower pot was dried at the room temperature for at least 1 day. The weight of the modified starch paste used for coating ranged from 16.2 to 17.8 grams (3 samples average $17.1 \mathrm{~g}, 3.2 \mathrm{~g}$ per pot by $100 \mathrm{~g}$ ).

\section{Water durability test}

Four types of samples were set for the water durability test.

- Paraffin coat: flower pot coated with paraffin wax (3 units).
- Starch coat: flower pot coated with tapioca starch (3 units).

- Modified starch coat: flower pot coated with modified tapioca starch (3 units).

- No coat: flower pot without coating (3 units).

Twelve flower pots were randomly set in the circle of radius $2.5 \mathrm{~m}$ with centering a water sprinkler without the margins of the sprinkled area for the purpose of sprinkling the water equally. The sprinkler watered at a flow rate of $924 \mathrm{~L} \mathrm{~h}^{-1}$, at the maximum volume, at $10 \mathrm{AM}$ for $1 \mathrm{~h}$ every day for 12 weeks. The flower pot was checked after 7-day (a week) sprinkling of water whether or not a serious crack occurred on the outside wall or the bottom surface of flower pot. If there was a $1.5 \mathrm{~cm}$ long crack on it, the flower pot was judged to be degraded.

\section{Toxicological testing}

According to the results of water durability test, and considering easiness in coating the surface of flower pot (using no brush), only paraffin-coated flower pot was used for toxicological testing. Leaching test and seed germination test were used to check negative effect on the ground and the germination.

The transfer factor of the heavy metal into the green leafy vegetable is the order, Cadmium $>$ Copper $>$ Nickel $>$ Lead $[20,21]$. In the previous report [11], the researchers measured the concentrations of 9 elements (Arsenic, Cadmium, Chromium, Copper, Lead, Manganese, Mercury, Nickel, Selenium) in the sludge cake. The concentrations of all elements except copper were quite lower than Thai standard [22]. The cadmium concentration was not more than $0.1 \mathrm{mg} \mathrm{kg}^{-1}$ [11]. The researchers then estimated that it was unnecessary to measure the cadmium concentration for the toxicity of sludge cake. Consequently, three heavy metals, lead, nickel and copper, were measured in this study. The concentrations of three heavy metals in sludge cake and Bang Len soil (clay) are shown in Table 1.

\section{Leaching test}

Procedures to determine the concentrations of heavy metals in the sample were total element analysis (wet digestion) [23]. Five-gram paraffin-coated flower pot was crushed and digested with $5 \mathrm{~mL}$ nitric acid for the total element analysis.

Procedure of leaching test was corresponding to USEPASW846, which complied with the standard method of Notification of Ministry of Industry Subject: Disposal of Wastes or Unusable Materials B.E.2005 [24]. 
Table 1 Concentration of 3 heavy metals in sludge cake, Bang Len soil (clay), Dindeedee soil (plant soil) and crushed material of paraffin-coated flower pot

\begin{tabular}{llll}
\hline Sample & \multicolumn{3}{l}{ Concentration $\left(\mathbf{m g ~ k g}^{\mathbf{- 1}}\right)$} \\
\cline { 2 - 4 } & Lead $(\mathrm{Pb})$ & Nickel (Ni) & Copper (Cu) \\
\hline Sludge cake & 0.588 & 0.167 & 10.40 \\
Bang Len soil (Clay) & 2.93 & 2.14 & 19.20 \\
$\begin{array}{l}\text { 100\% Soil (Dindeedee } \\
\text { soil: plant soil) }\end{array}$ & 0.003 & 0.001 & 14.50 \\
50\% Soil + 50\% FP & 0.968 & 0.668 & 14.61 \\
100\% FP & 2.388 & 1.644 & 15.45 \\
Standard & $400^{\mathrm{a}}$ & $1600^{\mathrm{a}}$ & $150^{\mathrm{b}}$ \\
\hline
\end{tabular}

Report from Office of Public Health and Environmental Technology Services, Faculty of Public Health, Mahidol University in March 2017

FP flower pot

a Soil Quality Standard, Thailand [22]

b Criteria for managing contaminated sites in British Columbia, Canada [25]

Five-gram paraffin-coated flower pot was also crushed and digested with $5 \mathrm{~mL}$ nitric acid for the leaching test.

The concentrations of lead, nickel and copper were measured by atomic absorption spectrophotometer (Flameless type). The detection limit of this method is $0.001 \mathrm{mg} \mathrm{kg}^{-1}$. Three samples were used for these testing.

\section{Seed germination test}

In the seed germination test, Chinese kale (Brassica oleracea var. alboglabra) was selected as the seed. A rectangular plastic basket (23 cm wide, $33 \mathrm{~cm}$ long, $8 \mathrm{~cm}$ deep) was used. It had many rectangular holes at the four-wall sides and bottom. Coconut coir were set about $2 \mathrm{~cm}$ depth on the bottom of the plastic basket for good ventilation and good water drainage. The plant soil was used for the seed germination.

The plant soil was brought from Dindeedee, Lopburi Province, Thailand (Dindeedee soil). This includes the fermented leaves of "Samanea saman" and is suitable for flowering plants, ornamental plants, and every vegetable. Their properties are (1) good friability (high porosity) and good ventilation, (2) high ability to keep moisture constant, and (3) good resistant to change to acid property or alkaline property.

The characteristics of the sludge cake, Bang Len soil (clay) and Dindeedee soil (plant soil) used in this experiment are shown in Table 2.

Crushed material of paraffin-coated flower pot was mixed at the appropriate ratio. Three groups were run. They were:
Table 2 Characteristics of the sludge cake, Bang Len soil (Clay) and Dindeedee soil (plant soil) used in this experiment

\begin{tabular}{|c|c|c|c|}
\hline Measure & Sludge cake & $\begin{array}{l}\text { Bang Len soil } \\
\text { (Clay) }\end{array}$ & $\begin{array}{l}\text { Dindeedee soil } \\
\text { (Plant soil) }\end{array}$ \\
\hline $\mathrm{pH}$ & 7.87 & 4.72 & 8.56 \\
\hline Moisture (\%) & 62.1 & 6.4 & 27.0 \\
\hline $\begin{array}{l}\text { Total organic carbon } \\
\left(\mathrm{mg} \mathrm{kg}^{-1}\right)\end{array}$ & 1356 & 216 & 7560 \\
\hline $\begin{array}{l}\text { Total phosphorus } \\
\left(\mathrm{mg} \mathrm{kg}^{-1}\right)\end{array}$ & 79 & 24 & 292 \\
\hline $\begin{array}{l}\text { Total nitrogen } \\
\left(\mathrm{mg} \mathrm{kg}^{-1}\right)\end{array}$ & 378 & 565 & 3046 \\
\hline Potassium (mg kg ${ }^{-1}$ ) & 120 & 774 & 1351 \\
\hline
\end{tabular}

Report from Central Lab, Faculty of Public Health, Mahidol University, in January 2017

- $100 \%$ Soil (control group): $2 \mathrm{~kg}$ of the soil.

- 50\% Soil and 50\% FP: $1 \mathrm{~kg}$ of the soil mixed with $1 \mathrm{~kg}$ of crushed paraffin-coated flower pot.

- 100\% FP: 2 kg of crushed paraffin-coated flower pot.

In each basket, 50 seeds of Chinese kale were planted in $1 \mathrm{~cm}$ depth ( 2 seeds in each hole). Watering was done at $10 \mathrm{AM}$ and $4 \mathrm{PM}$ every day. Observation period for germination test was set 50 days after planting. Three samples in each group were used for this testing.

\section{Statistical analysis}

Since the trials were mostly performed three times, only average was shown in this study. Difference in the average was examined by one-way ANOVA. In the comparison of the number of germination of Chinese kale at the same day in the seed germination test, Bonferroni correction was used for multiple comparisons. In the comparison of the number of germination of Chinese kale with that on the 5th day in the seed germination test, Dunnett correction was used for multiple comparisons.

Data handling and statistical analyses were carried out using SPSS version 24.0 (SPSS Japan). The difference was considered statistically significant for $p<0.05$.

\section{Results}

\section{Water durability test}

Table 3 shows the number of remaining flower pot at various times of observation period. The durability was different among four types of the coated flower pot. In weeks 1 and 2, all samples in four types were remaining. In week 3 , the no coat type began to break. In week 4 , the starch coat and the modified starch coat types also began to break. In week 6 , the paraffin coat type began to break. On this week, the other type had only 1 remaining set. In week 7 , 
Table 3 The number of remaining flower pot against the sprinkled water at various time of observation period

\begin{tabular}{|c|c|c|c|c|c|c|c|c|c|c|c|c|}
\hline \multirow[t]{2}{*}{ Types } & \multicolumn{12}{|c|}{ Week } \\
\hline & 1 & 2 & 3 & 4 & 5 & 6 & 7 & 8 & 9 & 10 & 11 & 12 \\
\hline Paraffin coat & 3 & 3 & 3 & 3 & 3 & 2 & 2 & 2 & 1 & 1 & 0 & 0 \\
\hline Starch coat & 3 & 3 & 3 & 2 & 2 & 1 & 1 & 0 & 0 & 0 & 0 & 0 \\
\hline Modified starch coat & 3 & 3 & 3 & 2 & 1 & 1 & 0 & 0 & 0 & 0 & 0 & 0 \\
\hline No coat & 3 & 3 & 2 & 2 & 2 & 1 & 1 & 1 & 0 & 0 & 0 & 0 \\
\hline
\end{tabular}

The number shows the remaining flower pot

Table 4 Result of total element analysis and leaching test of three heavy metals

\begin{tabular}{llcll}
\hline & & Flower pot & Thai Std & Canadian Std \\
\hline TEA $\left(\mathrm{mg} \mathrm{kg}^{-1}\right)$ & Lead $(\mathrm{Pb})$ & 9.55 & $400^{\mathrm{a}}$ & $375^{\mathrm{b}}$ \\
& Nickel $(\mathrm{Ni})$ & 1.29 & $1600^{\mathrm{a}}$ & $150^{\mathrm{b}}$ \\
& Copper $(\mathrm{Cu})$ & 10.38 & $-^{\mathrm{a}}$ & $150^{\mathrm{b}}$ \\
$\mathrm{LT}\left(\mathrm{gg} \mathrm{L}^{-1}\right)$ & Lead $(\mathrm{Pb})$ & 0.88 & $5000^{\mathrm{c}}$ & \\
& Nickel $(\mathrm{Ni})$ & 0.12 & $20,000^{\mathrm{c}}$ & \\
& Copper (Cu) & 0.57 & $25,000^{c}$ & \\
\hline
\end{tabular}

Figures show the average $(n=3)$

TEA total element analysis, $L T$ leaching test, Std standard value specified

a Soil Quality Standard, Thailand [22]

b Criteria for managing contaminated sites in British Columbia, Canada [25]

c Notification of the Ministry of Industry, Thailand [26]

the modified starch coat type had no remaining unit. In week 8 , the starch coat type had no remaining unit. In week 9 , the no coat type had no remaining unit. On this week, the paraffin coat type had still 1 remaining unit.

Judging from the results of the water durability test and easiness in coating the surface of flower pot, the researchers selected paraffin-coated flower pot as the best one. Consequently, it was used for the further experiment in this study.

\section{Toxicological testing}

The concentrations of lead and nickel in the total element test were lower than the value of the Soil Quality
Standard, Thailand [22]. Copper is not regulated in this act. The concentration of copper was lower than the value of Canadian standard [25] (Table 4).

The results of leaching test of three heavy metals were lower than the values of Notification of the Ministry of Industry, Thailand [26].

The concentrations of heavy metals in sludge cake, Bang Len soil (clay), 100\% Soil (Dindeedee soil: plant soil), 50\% Soil and $50 \%$ FP, and 100\% FP are shown in Table 1 . The concentrations of three elements except copper were quite lower (less than $10^{-2}$ ) than Thai standard [22]. The concentration of copper was about $10 \%$ compared with Canadian standard [25].

Table 5 shows the average number of germination of Chinese kale at various times of observation period. The number of Chinese kale with $100 \%$ Soil reached its peak on the 15 th day and continued. The ones with $50 \%$ Soil and $50 \% \mathrm{FP}$, and $100 \% \mathrm{FP}$ also showed the peak on the 15 th day and continued. There was no significant difference in the number of germination among the three groups.

The researchers measured the length of leaf in millimeter when the germination was found. When there were some leaves, the longest value was used. The leaf growth with $100 \%$ soil increased continuously (Table 6). The ones with 50\% Soil and 50\% FP, and 100\% FP also had same tendency. The one with $100 \%$ Soil was significantly longer than the one with $50 \%$ Soil and $50 \%$ FP from 10th day and the one with $100 \%$ FP from 20 th day. The ones in the two

Table 5 Average number of germination of Chinese kale at various time of observation period

\begin{tabular}{|c|c|c|c|c|c|c|c|c|c|c|}
\hline & \multicolumn{10}{|c|}{ Days after planting } \\
\hline & 5 th & 10th & 15 th & 20th & 25th & 30th & 35th & 40th & 45th & 50th \\
\hline 100\% Soil & 32.3 & $39.3^{* *}$ & $43.7^{* *}$ & $43.7^{* *}$ & $43.7^{* *}$ & $43.7^{* *}$ & $43.7^{* *}$ & $43.7^{* *}$ & $43.7^{* *}$ & $43.7^{* *}$ \\
\hline $50 \%$ Soil $+50 \% \mathrm{FP}$ & 32.7 & $40.0^{* *}$ & $44.3^{* * *}$ & $44.3^{* * *}$ & $44.3^{* * *}$ & $44.3^{* * *}$ & $44.3^{* * *}$ & $44.3^{* * *}$ & $44.3^{* * *}$ & $44.3^{* * *}$ \\
\hline $100 \% \mathrm{FP}$ & 33.7 & $39.3^{*}$ & $43.3^{* * *}$ & $43.3^{* * *}$ & $43.3^{* * *}$ & $43.3^{* * *}$ & $43.3^{* * *}$ & $43.3^{* * *}$ & $43.3^{* * *}$ & $43.3^{* * *}$ \\
\hline
\end{tabular}

Figures show the average $(n=3)$

FP flower pot

${ }^{*} p<0.05{ }^{* *} p<0.01{ }^{* * *} p<0.001$ (compared with 5 th day) 
Table 6 Average leaf $(\mathrm{mm})$ growth of Chinese kale at various time of observation period

\begin{tabular}{|c|c|c|c|c|c|c|c|c|c|c|}
\hline & \multicolumn{10}{|c|}{ Days after planting } \\
\hline & 5 th & 10th & 15th & 20th & 25th & 30th & 35 th & 40th & 45th & 50th \\
\hline 100\% Soil & 19.4 & 32.7 & 41.0 & 54.7 & $65.5^{*}$ & $74.0^{* *}$ & $81.2^{* * *}$ & $86.6^{* * *}$ & $92.4^{* * *}$ & $95.4^{* * *}$ \\
\hline $50 \%$ Soil $+50 \%$ FP & 17.2 & $25.2^{* * *}$ & $30.8^{* * *}, \#$ & $37.3^{* * * *}, \#$ & $40.4^{* * *}, \#$ & $42.4^{* * *}, \# \#$ & $43.2^{* * * * \#}$, & $44.5^{* * * *}$, & $45.0^{* * *}, \#$ & $46.1 * * *$, \# \\
\hline $100 \%$ FP & 22.2 & $30.9^{*}$ & $34.6^{* *}$ & $40.7^{* * * *}$, & $43.7^{* * *}, \# \#$ & $44.1^{* * *}, \# \#$ & $45.7^{* * *}, \# \#$ & $47.4^{* * *}, \#$ & $48.1^{* * *}, \#$ & $49.0^{* * *}$, \# \\
\hline
\end{tabular}

Figures show the average $(n=3)$

FP flower pot

${ }^{*} p<0.05{ }^{* *} p<0.01{ }^{* * *} p<0.001$ (compared with 5 th day)

\# $p<0.05^{\# \#} p<0.01$ (compared with 100\% Soil)

groups, 50\% Soil and 50\% FP, and 100\% FP, showed significantly smaller leaf than the one with $100 \%$ Soil. There was no significant difference between 50\% Soil and 50\% FP and $100 \%$ FP.

\section{Discussion}

Effect of various coating material on water durability of flower pot

The sprinkled water, $924 \mathrm{~L} \mathrm{~h} \mathrm{~h}^{-1}$, corresponded to $24 \mathrm{~mm} \mathrm{~h}^{-1}$ rain. Against such rain, paraffin coat had all units until 5 week and enough remained until 8 week when the other coats had no remaining unit. In the previous report [11], the flower pot, corresponding to the no coat type in this study, began to break at 15th day against about $26 \mathrm{~mm} \mathrm{~h}^{-1}$ rain. The results of the no coat type showed almost the same situation. Consequently, the paraffin-coated flower pot showed better water resistance. This may show that the paraffin wax strongly protects the sprinkled water, not only at the outside wall in which the water directly contacted but also at the bottom surface facing water on the ground. However, even the paraffin-coated flower pot cannot be used outdoors in the rainy season as the heavy rain would easily collapse it.

Paraffin wax is solid at the room temperature. Its melting point is between about 46 and $68^{\circ} \mathrm{C}$ [13], but begins to melt from approximately $37^{\circ} \mathrm{C}$ [27]. The research city was Bangkok, Thailand, and it was higher than $37^{\circ} \mathrm{C}$ in some days during research period. On such days, paraffin on the surface of flower pot had the possibility to melt and move down to the ground, and then the flower pot seemed to become weak against the sprinkled water. Even such conditions, the flower pot with paraffin coating may be used until 8 weeks.

\section{Effects of paraffin, coated material, on toxicity of sludge cake in the flower pot}

The concentrations of three toxicants, lead, nickel and copper, in the paraffin-coated flower pot in the total element analysis and leaching test were almost same as those reported in the previous report [11], but less than those reported earlier [2, 28]. Since there was no difference in the concentrations of heavy metals in the leaching test between the paraffin-coated flower pot (this study) and the no-coated one (the previous report [11]), the paraffin may have no preventive effect for the heavy metals to leach out. However, the concentrations in the leaching test were much lower than the standard of Thailand [26]. Even if the rain would attack the paraffin-coated flower pot, the heavy metals would little meld out into the ground. Paraffin itself is used for coating the surface of fruits [29] and eatable. Even if the paraffin of the paraffincoated flower pot would melt down to the ground due to a hot environment, the paraffin seems to have no negative effect on the ground.

Sludge cake has the possibility to have some chemicals [11]. Polyacrylamide used in the process to make sludge cake is relatively non-toxic [30]. Aluminum sulfate, however, is toxic to aquatic organism. Because the sludge cake has the possibility to contain it, the flower pot should be used in the area enough far from the water area and not be disposed into the water area after using it.

In the germination test, the groups containing crushed paraffin-coated flower pot showed no decreasing tendency in the number of germination of Chinese kale. Compared with the previous results [8], the average number of germination of Chinese kale in all three groups corresponded to that in $100 \%$ soil or $100 \%$ flower pot without paraffin coating. These results showed that paraffin had no suppressive effect on the germination.

Three most important nutrients are nitrogen $(\mathrm{N})$, phosphorus $(\mathrm{P})$, and potassium $(\mathrm{K})$. Nitrogen is used by plants for lots of leaf growth and good green color [31]. Phosphorous is used by plants to help form new roots, make seeds, fruit and flowers. It is also used by plants to help fight disease. Potassium helps plants make strong stems and keep growing fast. It is also used to help fight disease. The concentrations of nitrogen and phosphorous in sludge cake and Bang Len soil were about one tenth of the plant soil. The concentration of potassium in them was less than one-half of the plant soil. Lack in these 
three nutrients in the 50\% Soil and 50\% FP, and 100\% FP groups may play a major role to introduce the slow growth, namely small leaves maybe due to making fewer roots in the leaf growth in the two groups containing crushed paraffin-coated flower pot. Consequently, the paraffin seems to have no suppressive effect on the leaf growth.

Coating flower pot by paraffin has the advantage point. It enables us to use the flower pot longer than no-coated one. The usage of the paraffin-coated one becomes about 2 months from 1 month of no-coated one in the area under protecting rain in an industrial site. Although the paraffin does not prevent the toxicity of the sludge cake in the flower pot, it itself has no health hazard. It is recommended to coating the flower pot with paraffin for the purpose of using it for a long time.

The researchers should mention possible limitation. Researchers were allowed to use the machine for only a limited time and then failed to make enough number of flower pots for durability test. In the leaching test and germination test, it was impossible to show the standard deviations.

Although the sludge from the industry has the possibility to content the harmful bacteria [10], even after both chemical and biological treatments, it was not checked. Since the investigators focused on prolonging the lifetime of flower pot on the ground, the economical convenience of the paraffin-coated flower plots was not evaluated. The durability of flower pot in actual use, such as filled with irrigated soil, was also not estimated. However, this study shows that the paraffin-coated flower pot has the possibility to reuse the sludge cake in the horticultural practice of growing the ornamental plant.

\section{Conclusion}

Paraffin prolonged the life of flower pot on the ground until 5 weeks at least and may be 8 weeks. It has no preventing effect on the toxicity of the sludge cake in the flower pot, although the sludge cake in the flower pot seems to have no negative effect on the environment at disposing it. The paraffin-coated flower pot seemed to have no suppressive effect on the seed germination or leaf growth. This paraffin-coated flower pot has the possibility to reuse the sludge cake in the horticultural practice of growing the ornamental plant.

\section{Abbreviation}

FP: flower pot.

\section{Authors' contributions}

UK conceived the study. UK and CP participated in the design of the study, performed the study, and drafted the manuscript. IM helped to make the design and to draft the manuscript, and performed the statistical analysis. All authors read and approved the final manuscript.

\section{Author details}

${ }^{1}$ Faculty of Public Health, Bangkokthonburi University, Khet Taweewatana, Bangkok 10170, Thailand. ${ }^{2}$ Graduate School of Health and Nursing Science, Wakayama Medical University, Mikazura 580, Wakayama 641-0011, Japan.

\section{Acknowledgements}

The authors impress and appreciate associate professor Piangchan Rojanavipart, Faculty of Public Health, Bangkokthonburi University, for her kindness to give us vulnerable advice, associate professor Rawiwan Sangchai, Dean Faculty of Public Health, Bangkokthonburi University for her kindly support in this research, and Miss Supaporn Pilathong, Miss Jiraphon Sookin, Miss Bangon Kwanyeun, the third year students of Faculty of Public Health, Bangkokthonburi University for taking care Chinese kale spouts during the experiment. Many thanks forward to Associate Professor Krisana Teankaprasith, Head of Central Laboratory, Faculty of Public Health, Mahidol University for the chemical analysis. Again the authors appreciate Miss Pramuan Sunpakawe, Research and Development section, Tenma Paper Mill (Thailand) for preparing new sludge cake.

\section{Competing interests}

The authors declare that they have no competing interests.

\section{Availability of data and materials}

Data sharing was not applicable to this article as no datasets were generated or analyzed during the current study.

\section{Consent for publication}

Not applicable.

Ethics approval and content to participate

Not applicable.

\section{Funding}

There was no funding for the research.

\section{Publisher's Note}

Springer Nature remains neutral with regard to jurisdictional claims in published maps and institutional affiliations.

Received: 19 June 2018 Accepted: 20 October 2018

Published online: 22 November 2018

\section{References}

1. Tchobanoglous G, Burton FL, David Stensel D. Wastewater engineering: treatment and reuse. 4th ed. McGraw Hill Higher Education: Singapore; 2003.

2. Rashid MT, Barry D, Goss M. Paper mill biosolids application to agricultural lands: benefits and environmental concerns with special reference to situation in Canada. Soil Environ. 2006;25(2):85-98.

3. Thompson G, Swain J, Kay M, Forster CF. The treatment of pulp and paper mill effluent: a review. Bioresour Technol. 2001;77(3):275-86.

4. Pokhrel D, Viraraghavan T. Treatment of pulp and paper mill wastewater-a review. Sci Total Environ. 2004;333(1-3):37-58.

5. U.S. Environmental Protection agency, Landfills. Waste-non-hazardous waster - Municipal solid waste; 2016. Landfillshttps://archive.epa.gov/epawa ste/nonhaz/municipal/web/html/landfill.html. Accessed 31 Oct 2018.

6. Okuno N, Ishikawa Y, Shimizu A, Yoshida M. Utilization of sludge in building material. Water Sci Technol. 2004;49(10):225-32.

7. Kongmuang U, Kiykaew D, Morioka I. Construction technique of disposable bin from sludge cake and its environmental risk. Environ Health Prev Med. 2015;20:28-35. https://doi.org/10.1007/s12199-014-0420-8 (Epub 2014 Nov 7.).

8. Tiago Natal-da-Luz T, Tidona S, Jesus B, Morais PV, Sousa JP. The use of sewage sludge as soil amendment. The need for an ecotoxicological evaluation. J Soils Sediments. 2009;9:246-60. 
9. Soundhirarajan K, Leena R. Utilization and application of sewage sludge as agricultural compost. Int J Adv Eng Res Develop. 2018;5(4):270-9.

10. Department for Environment Food \& Rural Affairs. Sewage sludge in agriculture: code of practice for England, Wales and Northern Ireland (Published 23 May 2018). https://www.gov.uk/government/publications/sewage-sludg e-in-agriculture-code-of-practice/sewage-sludge-in-agriculture-code-ofpractice-for-england-wales-and-northern-ireland. Accessed 3 Oct 2018.

11. Kongmuang U, Sritanaudomchai $\mathrm{H}$, Morioka I. Potential use of sludge cake from paper mill wastewater treatment as degradable flower pot. Environ Health Prev Med. 2016;21(4):258-64. https://doi.org/10.1007/s12199-0160523-5 (Epub 2016 Mar 10.)

12. Pathology Labs High Density Shelves for Paraffin and Tissue Block Storage. http://www.southwestsolutions.com/healthcare/pathology-lab-paraffinand-tissue-block-storage-high-density-shelves. Accessed 3 Oct 2018.

13. Paraffin wax. https://en.wikipedia.org/wiki/Paraffin_wax. Accessed 3 Oct 2018.

14. Nunes MA, Ormsby CM, Patel V, Peng T, Boyd A. Paraffin wax as a sealant in sorptivity testing. J Mater Civil Eng. 2015;27(8):04014218. https://doi. org/10.1061/(ASCE)MT.1943-5533.0000508.

15. How to Make Paraffin Wax. https://www.leaf.tv/articles/how-to-make-paraf fin-wax/. Accessed 3 Oct 2018.

16. Tapioca. https://en.wikipedia.org/wiki/Tapioca. Accessed 3 Oct 2018.

17. Vaclavik V, Christian WW. Starches in food. In: Vaclavik V, Christian WW, editors. Essentials of food science. 3rd ed. Berlin: Springer; 2007. p. 49-67.

18. Gotlieb KF, Capelle A. Starch derivatization: Fascinating and unique industrial opportunities. Wageningen: Wageningen Academic Publishers; 2005.

19. Modified starch. https://en.wikipedia.org/wiki/Modified_starch. Accessed 3 Oct 2018

20. Jayadev, Puttaih ET. Assessment of heavy metals uptake in leafy vegetables grown on long term wastewater irrigated soil across Vrishabhavathi River, Bangalore, Karnataka. J Environ Sci Toxicol Food Technol. 2013;7(6):52-5.

21. Intawongse M, Dean JR. Uptake of heavy metals by vegetable plants grown on contaminated soil and their bioavailability in the human gastrointestinal tract. Food Addit Contam. 2006;23(1):36-48.
22. Pollution Control Department, Ministry of Natural Resources and Environment, Thailand. Soil quality standards, http://www.pcd.go.th/info_serv/ reg_std_soil01.html. (in Thai) Accessed 3 Oct 2018.

23. Eaton $A \bar{D}$, American Public Health Association (APHA), American Water Works Association (AWWA), \&Water Environment Federation (WEF). Method 3030D "Digestion for metal" (Total element analysis \& leaching test), In: Standard Methods for the examination of Water \& Wastewater (21st Ed). Washington, D.C., USA, APHA-AWWA-WEF, 2005.

24. Hazardous Waste Test Methods/SW-846. https://www.epa.gov/hw-sw846. Accessed 3 Oct 2018.

25. Biomedical Waste in a MOE British Colombia Report names needles called sharps as biomedical waste. http://a100.gov.bc.ca/pub/eirs/finishDown loadDocument.do;jsessionid=3wMMZMyZPBD13LLq7KR8yB70mBx6d] LvqFzYs2TGvMnLRmkzZT3x!-952645365?subdocumentld=3732 Accessed 3 Oct 2018

26. Notification of Ministry of Industry Re: Industrial Waste Disposal B.E. 2548 (2005) http://www.env.go.jp/en/recycle/asian_net/Country_Information/ Law_N_Regulation/Thailand/Re_Industrial_Waste_Disposal_BE2548(2005). pdf. Accessed 3 Oct 2018.

27. Freund M, Mozes G. Paraffin products: properties, technologies, applications. Translated by Jakab E. Amsterdam: Elsevier Science Publishers, 1982. p. 121.

28. Legendre BL, Bischoff KP, Gravois KA, Hendrick RD, Arceneaux AE. Sugarcane yields and soil analysis following application of paper-mill sludge. J Am Soc Sugar Cane Tech. 2004;24:60-9.

29. Verma LR, Joshi VK, editors. Postharvest technology of fruits and vegetables: handling, processing, fermentation and waste management. General concepts and principles, vol. 1. New Delhi: Indus Pub. Co; 2000.

30. Woodrow JE, Seiber JN, Miller GC. Acrylamide release resulting from sunlight irradiation of aqueous polyacrylamide/iron mixtures. J Agric Food Chem. 2008;56(8):2773-9. https://doi.org/10.1021/jf703677v (Epub 2008 Mar 20.).

31. Plant nutrients in the soil. https://www.dpi.nsw.gov.au/agriculture/soils/ improvement/plant-nutrients. Accessed 3 Oct 2018.

\section{Submit your manuscript to a SpringerOpen ${ }^{\circ}$ journal and benefit from:}

- Convenient online submission

- Rigorous peer review

- Open access: articles freely available online

- High visibility within the field

- Retaining the copyright to your article

Submit your next manuscript at springeropen.com 